\title{
Diversifikasi Pengolahan Jamur Tiram pada Kelompok Tani Saraso, Kenagarian Batu Balang, Kecamatan Harau, Kabupaten Lima Puluh Kota
}

\author{
Tety Desrita Handayani, Mimi Harni, Fidela Violalita, dan Nurzarrah Tazar \\ Jurusan Teknologi Pertanian, Politeknik Pertanian Negeri Payakumbuh, Sumatera Barat, 26271. Indonesia \\ E-mail: tety.desritahandayani@politanipyk.ac.id
}

Keywords: dendeng oyster mushroom, diversification, oyster mushroom beef, processed food

Kata Kunci: beef jamur tiram, dendeng jamur tiram, diversifikasi, produk olahan

\begin{abstract}
Oyster mushrooms are widely cultivated by Saraso farmer group Kenagarian Batu Balang, Harau District, Lima Puluh Kota Regency. The purpose of the activity was to increase knowledge and skills and empower the women of the Saraso Farmers Group, in the diversification of processed oyster mushroom products in order to increase the selling value. So far, the oyster mushrooms they cultivate are sold in fresh mushrooms, and only a few sell in processed food. The hope is that with this activity, the community can make various processed oyster mushrooms to add value to the sale which is expected to raise the family economy. The activity method was carried out by demonstration and hands-on practice. The results of community service activities showed that the women of the Saraso farmer group are able to process oyster mushrooms into various ready-to-consume products. Various processed mushrooms are made, namely Dendeng oyster mushroom, oyster mushroom beef, oyster mushroom satay, oyster mushroom shredded and additional materials, namely making sauces and chili sauce. This activity succeeded in arousing the motivation of the Saraso farmer groups in making variations of processed oyster mushrooms.
\end{abstract}

\footnotetext{
ABSTRAK

Jamur tiram banyak dibudidayakan oleh kelompok tani Saraso, Kenagarian Batu Balang, Kecamatan Harau, Kabupaten Lima Puluh Kota. Tujuan dari kegiatan ini adalah meningkatkan pengetahuan dan keterampilan dan memberdayakan ibu-ibu Kelompok Tani Saraso, dalam diversifikasi produk olahan jamur tiram guna menambah nilai jual. Selama ini jamur tiram yang mereka budidayakan dijual dalam bentuk mentah, dan hanya sedikit yang menjual dalam bentuk olahan. Harapannya dengan kegiatan ini, masyarakat dapat membuat aneka olahan jamur tiram untuk menambah nilai jual yang harapannya akan mengangkat perekonomian keluarga. Metode kegiatan dilakukan dengan demonstrasi dan praktek langsung. Hasil kegiatan pengabdian masyarakat menunjukkan bahwa, ibu-ibu kelompok tani Saraso mampu melakukan pengolahan jamur tiram menjadi aneka produk siap konsumsi. Aneka olahan jamur yang dibuat yaitu Dendeng jamur tiram, Beef jamur tiram, Sate jamur tiram, Abon jamur tiram dan materi tambahan yaitu pembuatan saos dan sambal. Kegiatan ini berhasil membangkitkan motivasi kelompok tani saraso dalam membuat variasi olahan jamur tiram.
} 


\section{PENDAHULUAN}

Kenagarian Batu Balang, secara administratif berada di Kecamatan Harau, Kabupaten Lima Puluh Kota, Provinsi Sumatera Barat. Masyarakat Kenagarian Batu Balang banyak berprofesi sebagai petani, salah satunya yaitu bertani jamur tiram. Jamur tiram merupakan salah satu komoditas yang sedang diminati masyarakat untuk memenuhi kebutuhan pangan. Hal ini dapat dilihat dari permintaan yang terus meningkat setiap tahunnya. Namun, selama ini hasil budidaya jamur tiram di Nagari Batu Balang hanya dijual dalam bentuk mentah, sehingga nilai jualnya rendah.

Kandungan gizi jamur tiram sangat lengkap diantaranya dalam 100 gram jamur tiram terdapat karbohidrat sekitar 64\%, protein 15\%, lemak $2.6 \%$, serta mineral-mineral lain seperti Ca dan Fe. Selain sumber protein, vitamin dan jamur tiram juga berfungsi sebagai antikanker, antikolesterol serta antioksidan (Sumarsih, 2015). Jamur tiram putih juga mengandung protein yang tinggi dan memiliki asam amino essensial yang cukup lengkap dan baik untuk tubuh (Andoko dan Parjimo, 2007). Tingginya kandungan zat gizi pada jamur tiram, sehingga cocok untuk dikembangan menjadi pangan yang memiliki nilai lebih pengganti sumber pangan lainnya.

Berdasarkan hasil survei, masih sangat terbatas petani yang memiliki pengetahuan dan keterampilan dalam melakukan pengolahan jamur tiram menjadi berbagai produk olahan jamur tiram untuk meningkatkan nilai jualnya. Pengolahan jamur tiram menjadi berbagai produk (dendeng, abon, beef dan sate) merupakan upaya yang dilakukan untuk menambah nilai jual jamur tiram. Prospek inilah yang membuat jamur tiram dapat dijadikan sebagai sebuah ide cemerlang untuk membuka lahan bisnis baru bagi mereka yang berjiwa pengusaha. Selain itu juga dapat membuka lapangan pekerjaan baru untuk mengurangi pengangguran di Kenagarian Batu Balang.

Tujuan dari kegiatan pengabdian masyarakat ini adalah melakukan pelatihan pengolahan jamur tiram menjadi berbagai macam produk olahan serta memsosialisasikan nilai tambah sehingga diharapkan akan menjadi alternatif penghasilan masyarakat Kenagarian Batu Balang. Selain itu guna membekali kelompok tani tentang wawasan untuk menjadi wirausahawan dengan mendirikan industri kecil dan menengah yang mampu menyerap tenaga kerja di daerah tersebut.

\section{METODE}

Kegiatan dilakukan di Kelompok Tani Saraso, Kenagaraian Batu Balang, Kecamatan Harau, Kabupaten Lima Puluh Kota. Pelaksanaan kegiatan dilakukan pada tanggal 23 September - 11 November 2020. Kegiatan penyuluhan dan pelatihan (demonstrasi) ini diikuti oleh 10 orang yang merupakan perwakilan dari Kelompok Tani Saraso, Kenagaraian Batu Balang. Bahan utama yang diperlukan dalam kegiatan pengabdian ini adalah jamur tiram. Sedangkan bahan penunjangnya, antara lain tempe, gula pasir, tepung terigu, tepung beras ketan, tepung tapioka, air mineral (air bersih), garam, keju dan bumbu-bumbu. Peralatan yang dibutuhkan adalah pisau, blender, kompor, panci, wajan, pengaduk, timbangan, kemasan plastik, pengukus dan lainnya.

Metode yang digunakan dalam kegiatan pengabdian masyarakat ini adalah metode ceramah, praktek, dan diskusi. Metode ceramah digunakan untuk menjelaskan materi tentang diversifikasi olahan jamur tiram. Metode praktek digunakan untuk praktek membuat olahan produk berbasis jamur tiram, mulai dari pengolahan dan pengemasan. Teknik pengemasan untuk meningkatkan mutu dan harga jual dengan packing yang berkualitas. Evaluasi dengan cara diskusi dilakukan pada saat kegiatan berlangsung untuk mengetahui respon dari peserta. Disamping itu dilakukan pengumpulan data dengan metode deskriptif. Data dan informasi yang terkumpul diolah dan 
dianalisis secara kualitatif. Kegiatan yang telah dilaksanakan ini dilakukan melalui observasi, wawancara, pelatihan, dan bimbingan teknis, serta dokumentasi.

\section{HASIL DAN PEMBAHASAN}

Diversifikasi produk olahan jamur tiram telah dilaksanakan di Kelompok Tani Saraso, Kenagarian Batu Balang, Kecamatan Harau, Kabupaten Lima Puluh Kota. Kegiatan yang telah dilaksanakan adalah penyuluhan dan demonstrasi pengolahan; motivasi kewirausahaan; ujian pembuatan produk yang telah diajarkan, dan terakhir yaitu evaluasi dan pemasaran.

\section{Penyuluhan dan Demontrasi Pengolahan}

Kegiatan pertama yang telah dilakukan berupa penyuluhan dilanjutkan dengan demonstrasi pengolahan bersama kelompok tani Saraso, Kenagarian Batu Balang. Kegiatan penyuluhan diversifikasi produk olahan jamur tiram bertujuan untuk meningkatkan pengetahuan sekaligus keterampilan anggota kelompok tani, sehingga dari itu diharapkan dapat meningkatkan pendapatan masyarakat Nagari Batu Balang. Setelah kegiatan penyuluhan, kemudian dilanjutkan dengan kegiatan praktek atau demonstrasi.

Hasil penyuluhan dan demonstrasi adalah khalayak sasaran (kelompok tani Saraso) berkontribusi langsung, yaitu mengikuti kegiatan penyuluhan dan demontrasi pengolahan dari awal hingga akhir. Pada pertemuan pertama ini, kegiatan penyuluhan dan demonstrasi pengolahan jamur tiram menjadi Dendeng jamur tiram, Beef jamur tiram, Sate jamur tiram, Abon jamur tiram, dan produk saos serta sambal, yang diikuti oleh 10 orang. Jumlah peserta pada penyuluhan dan demonstrasi produk dibatasi mengingat protokol kesehatan Covid-19 yang mengharuskan melakukan jaga jarak.



Gambar 1. Kegiatan penyuluhan pengolahan jamur tiram menjadi aneka produk 


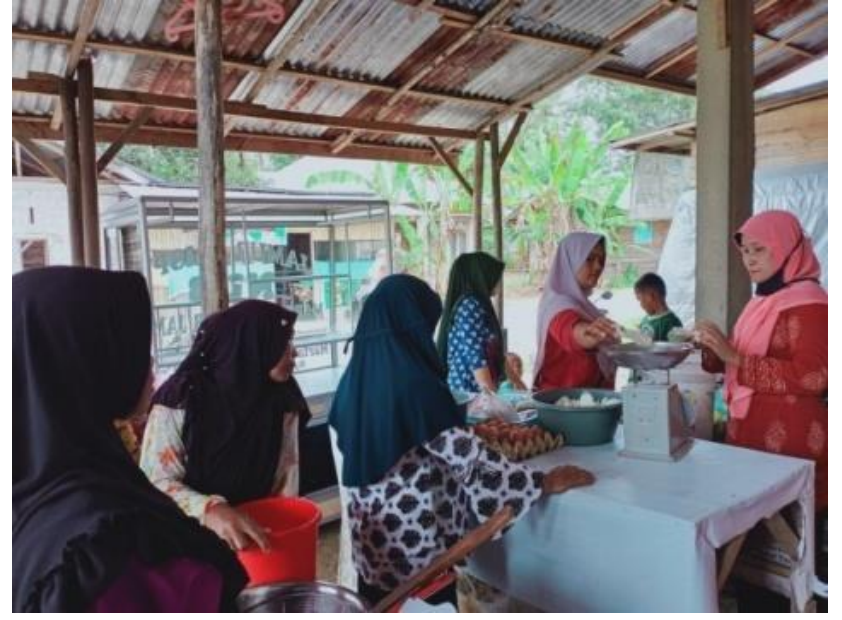

Gambar 2. Demonstrasi pengolahan produk Dendeng dan Beef jamur tiram

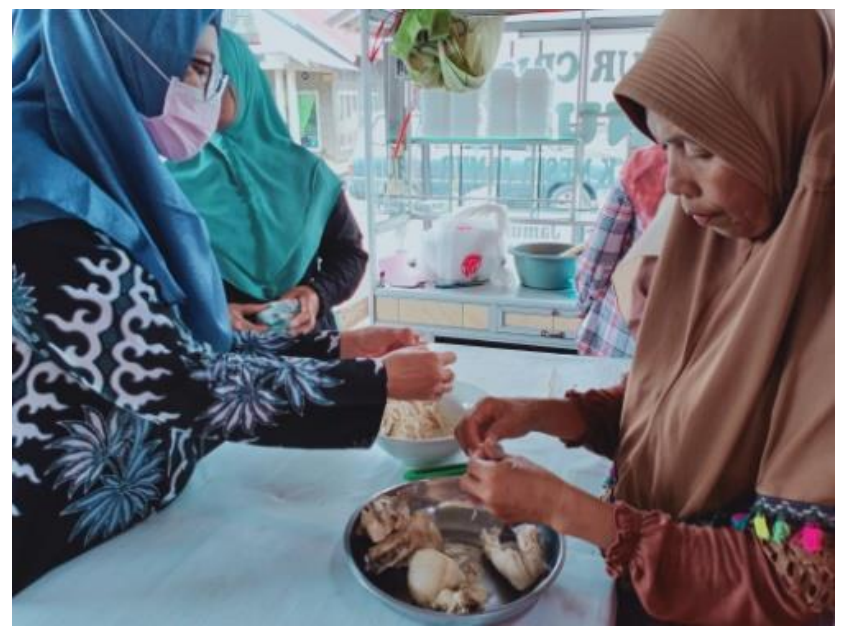

Gambar 4. Demonstrasi pembuatan produk Sate jamur tiram

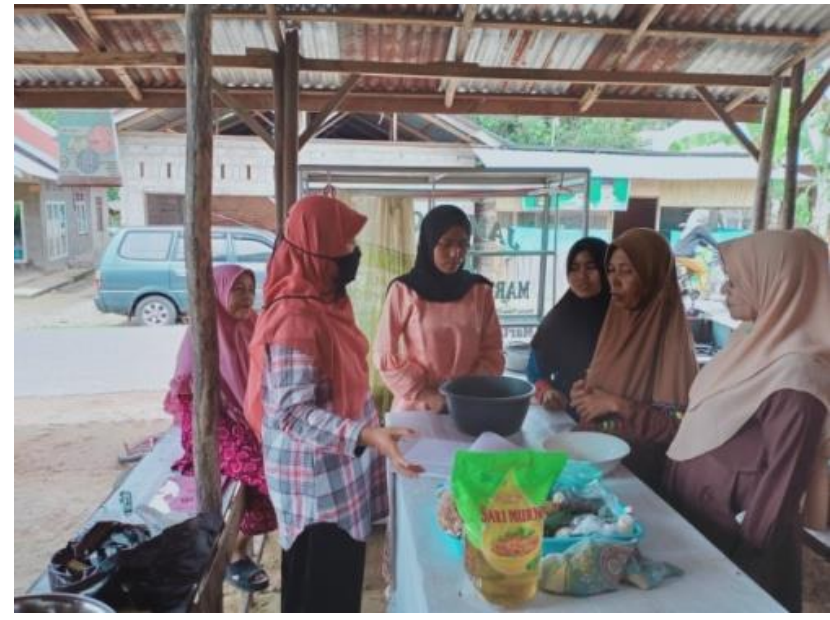

Gambar 3. Demonstrasi pembuatan produk Abon jamur tiram

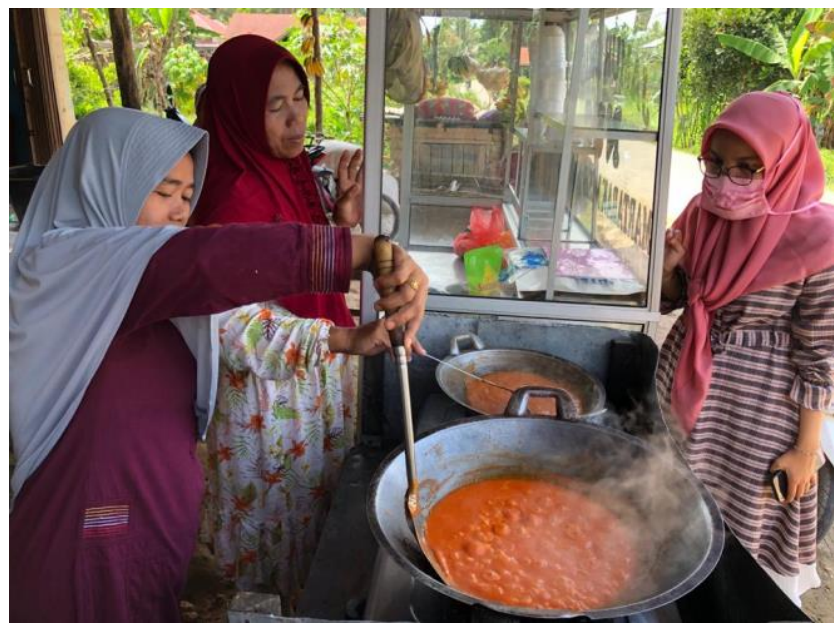

Gambar 5. Demonstrasi pengolahan produk Saos dan Sambal

\section{Motivasi Kewirausahaan}

Kegiatan kedua yang telah dilaksanakan berupa motivasi kewirausahaan ke kelompok tani Saraso tentang pentingnya diversifikasi pengolahan yang akan memberikan nilai tambah terhadap jamur yang mereka budidayakan, sehingga akan meningkatkan perekonomian keluarga maupun kelopok tani tersebut. Kelompok tani dibekali dengan materi pentingnya usaha mandiri (kewirausahaan), kiat-kiat usaha dan memanfaatkan peluang yang ada, guna meningkatkan nilai tambah produk. Setelah melakukan kegiatan motivasi kewirausahaan kemudian dilanjutkan dengan ujian pengolahan yang telah didemonstrasikan pada pertemuan sebelumnya. 


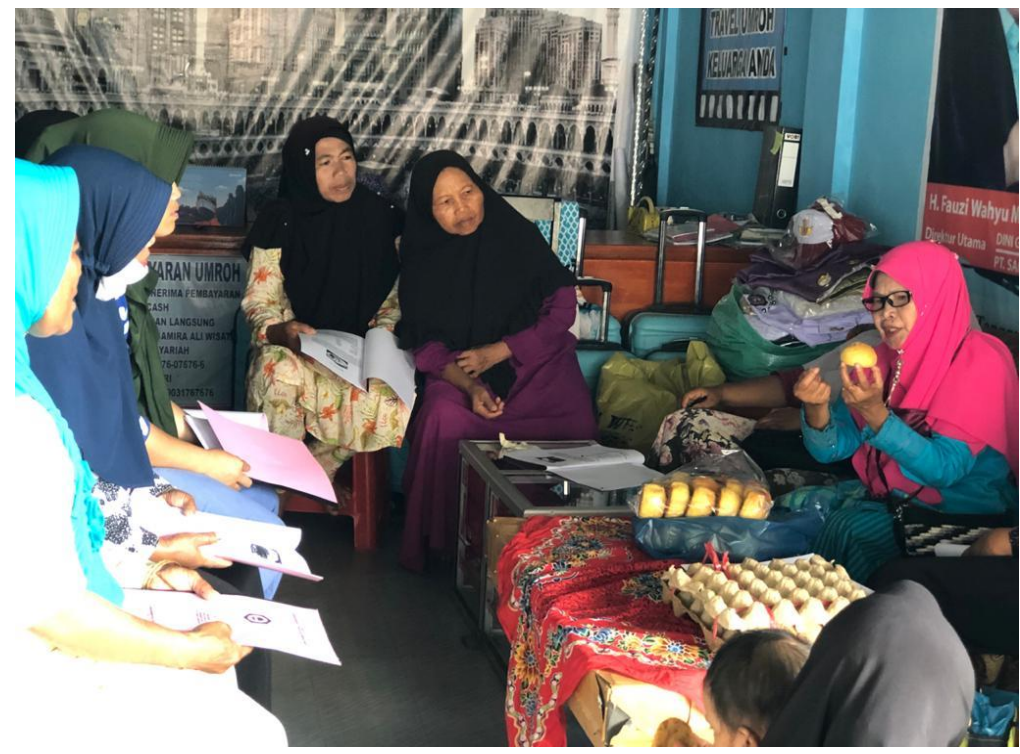

Gambar 6. Kegiatan Motivasi Kewirausahaan

Hasil dari kegiatan ini menunjukkan bahwa Kelompok Tani Saraso, Kenagarian Batu Balang cukup antusias dan mengapresiasi kegiatan yang dilaksanakn. Hal ini terlihat dengan banyaknya informasi yang disampaikan oleh anggota kelompok tani dalam wawancara yang dilakukan oleh tim pengabdian menyangkut kondisi terakhir hasil budidaya jamur tiram. Besar harapan mereka, mereka mampu melakukan diversifikasi pengolahan sehingga akan meningkatkan perekonomian keluarga.

\section{Evaluasi Produk}

Setelah mengikuti kegiatan penyuluhan dan demonstrasi oleh tim pengabdian, rangkaian kegiatan selanjutnya dari kegiatan ini adalah evaluasi terhadap produk yang telah dibuat. Dengan diadakannya kegiatan ini, harapannya kelompok tani dapat melakukan pengolahan jamur menjadi aneka produk. Pada tahap ini juga dilakukan kegiatan evaluasi dengan cara wawancara dan monitoring langsung kepada anggota kelompok tani yang terlibat dalam kegiatan ini untuk mengetahui sejauh mana mereka mampu mengolah jamur tiram sesuai dengan yang sudah didemonstrasikan sebelumnya. Hasil dari kegiatan ini yaitu, anggota kelompok tani mampu membuat produk olahan jamur tiram. Hal ini terlihat dengan produk yang mereka buat memiliki rasa yang enak dan penampakan yang menarik.
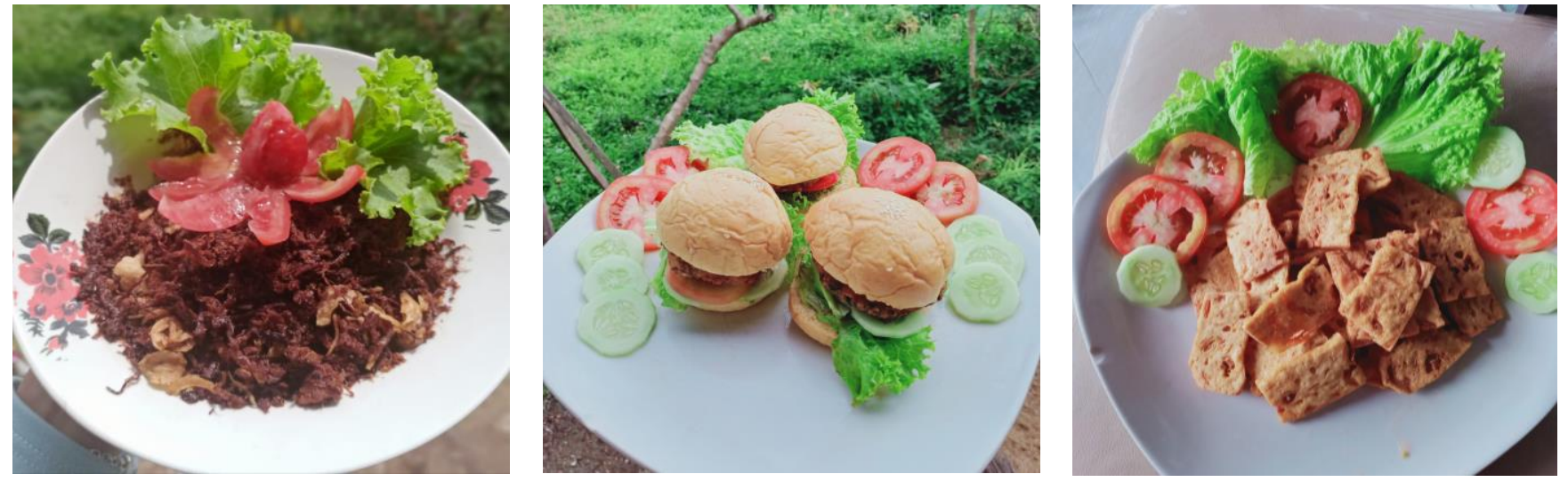

Gambar 7. Produk olahan jamur tiram hasil diversifikasi 


\section{Pemasaran}

Strategi pemasaran aneka olahan jamur tiram menjadi materi penutup, sehingga peserta mendapatkan gambaran tentang pemasaran olahan jamur tiram. Evaluasi terhadap tingkat partisipasi ini dilakukan untuk setiap rangkaian kegiatan dengan cara memonitoring dan mengevaluasi hasil pembuatan produk. Hal ini untuk memastikan tingkat pengetahuan kelompok mitra sebelum dan setelah diadakannya kegiatan penyuluhan. Dalam proses evaluasi menggunakan metode praktik langsung. Dari hasil kegiatan bersama kelompok mitra diperoleh hasil yang positif. Dari hasil evaluasi didapatkan bahwa partisipasi anggota sangat tinggi dan ini terbukti dari tingkat keberhasilan anggota dalam pembuatan produk.

Strategi pemasaran adalah logika pemasaran dimana unit bisnis berharap untuk menciptakan nilai dan memperoleh keuntungan dari hubungannya dengan konsumen (Kotler \& Amstrong, 2008). Pada kesempatan ini, tim pengabdian menyampaikan materi penyuluhan strategi pemasaran secara konvensional dan juga secara digital.

Kemajuan teknologi informasi yang semakin mendunia menyebabkan perubahan perilaku konsumen dalam membeli produk. Konsumen pada saat ini menuntut layanan permasaran online melalui internet yang mudah, cepat dan dapat diakses dari mana saja dan kapan saja. Pada dasarnya konsumen selalu menginginkan kemudahan bila ingin membeli suatu produk (Wandanaya, 2012). Sistem pemasaran digital merupakan salah satu media pemasaran yang saat ini sedang banyak diminati oleh masyarakat untuk medukung ber-bagai kegiatan yang dilakukan. Mereka sedikit demi sedikit mulai meninggalkan model pe-masaran konvensional/tradisional beralih ke pemasaran modern, yaitu digital marketing. Dengan digital marketing komunikasi dan transaksi dapat dilakukan setiap waktu/real time dan bisa mengglobal atau mendunia (Pradiani, 2017).

\section{KESIMPULAN}

Berdasarkan hasil pelatihan atau pengabdian yang sudah dilakukan, dapat disimpulkan bahwa peserta dapat berpartisifasi aktif dalam mengikuti kegiatan pelatihan mulai dari materi teori sampai prakteknya, peserta dapat memahami tentang pengolahan pangan, tentang gizi, dan memilih bahan dan proses pengolahan produk jamur tiram putih. Peserta dapat melakukan praktek pengolahan jamur tiram menjadi berbagai produk seperti dendeng, beef, sate, abon, saos, dan sambal jamur tiram yang memiliki citarasa yang enak dan mengandung zat gizi nabati yang dominan. Aneka olahan jamur tiram dapat dijadikan salah satu peluang usaha. Kegiatan pengabdian masyarakat ini diharapkan mampu menjadi motivasi dan mendorong jiwa kewirausahaan Kelompok Tani Saraso Kenagarian Batu Balang, Kecamatan Harau Kabupaten Lima Puluh Kota. Kedepannya produk bisa didaftarkan ke Dinas Kesehatan setempat untuk bisa mendapatkan pelatihan Keamanan Pangan dan Sertifikat PIRT.

\section{DAFTAR PUSTAKA}

Andoko, A. dan Parjimo. 2007 Budi Daya Jamur: Jamur Kuping, Jamur Tiram, dan Jamur Merang. Agromedia Pustaka, Jakarta.

Kotler, P; Amstrong, G. 2008. Prinsip-prinsip Pemasaran. Jilid 1. Jakarta (ID): Erlangga.

Pradiani, T. 2017. Pengaruh Sistem Pemasaran Digital Marketing Terhadap Peningkatan Volume Penjualan Hasil Industri Rumahan. Jibeka. 11(2): 46-53. https://doi.org/ 10.32812/jibeka.v11i2.45 
Rangkuti, Freddy. 2010. Analisis SWOT Teknik Membedah Kasus Bisnis. Jakarta: PT. Gramedia Pustaka Utama.

Sumarsih, Sri. 2015. Bisnis Bibit Jamur Tiram. Jakarta: Penebar Swadaya.

Wandanaya, AB. 2012. Pengaruh Pemasaran Online Terhadap Keputusan Pembelian Produk. CCIT Journal. 5(2): 174-178. 